\title{
Experimental study of a novel tumstatin on C6 brain glioma in vitro
}

\author{
PENGGUO ZHANG $^{1 *}$, QINGWEI ZHOU ${ }^{2 *}$, LIN TIAN $^{3}$, XIANGYU ZHOU $^{4}$, YUE ZHOU $^{5}$ and JIAJUN CHEN ${ }^{4}$ \\ ${ }^{1}$ Department of Radiology, Jilin University Second Hospital; ${ }^{2}$ Department of Biology and Medical Engineering, School of \\ Regenerative Medicine; ${ }^{3}$ Department of Biology and Medical Engineering, School of Pharmacy; ${ }^{4}$ Department of Neurology, \\ China-Japan Union Hospital, Jilin University, Changchun, Jilin 130022; 5 Department of Biological Preparation, School of \\ Pharmacy, Nanjing University of Traditional Chinese Medicine, Nanjing, Jiangsu 210046, P.R. China
}

Received January 30, 2016; Accepted February 23, 2017

DOI: $10.3892 / \mathrm{ol} .2017 .6507$

\begin{abstract}
To investigate the effect of a novel tumstatin on C6 brain glioma cells, the MTT method was used to detect C6 glioma cell proliferation activity at different time periods (12, 48 and $72 \mathrm{~h})$. Cell cycle distribution and apoptosis rate were detected by flow cytometry, and the acridine orange/ethidium bromide staining method was used to detect apoptosis and mitochondrial membrane potential by fluorescence microscopy. Novel tumstatin had an evident inhibitory effect on C6 glioma cells, and the most notable impact emerged after $48 \mathrm{~h}$. The following were observed under the fluorescence microscope: Characteristic morphological changes of cell apoptosis were typically observed in the novel tumstatin $(2,000 \mu \mathrm{g} / \mathrm{ml})$ group; mitochondrial membrane potential decreased significantly $(\mathrm{P}<0.05)$; the cells in the $\mathrm{G} 0 / \mathrm{G} 1$ phase significantly increased $(\mathrm{P}<0.05)$; and the number of cells in the $\mathrm{S}$ phase was reduced. There was an increase in cell apoptosis rate in the novel tumstatin $(2,000 \mu \mathrm{g} / \mathrm{ml})$ group compared with the novel tumstatin $(1,000 \mu \mathrm{g} / \mathrm{ml})$ group and the Mock group, and the data were statistically significant $(\mathrm{P}<0.05)$. Novel tumstatin may reduce the mitochondrial membrane potential, inducing cell apoptosis, and thereby exerting antitumor activity.
\end{abstract}

\section{Introduction}

Glioma is the most common intracranial primary tumor, with invasive growth and high postoperative recurrence. It is a serious threat to the life and health of patients. At present, the pathogenesis of glioma is not clear (1). Previous studies have

Correspondence to: Professor Jiajun Chen, Department of Neurology, China-Japan Union Hospital, Jilin University, 126 Xiantai Street, Changchun, Jilin 130022, P.R. China

E-mail: chenjiajun999@sina.com

*Contributed equally

Key words: novel tumstatin, C6 glioma cell, flow cytometry, cell apoptosis demonstrated that the occurrence and development of glioma is associated with apoptosis (2-4). The traditional treatment principle is postoperative radiotherapy prior to chemotherapy, or either chemotherapy or radiotherapy alone, but it is difficult to improve the clinical efficacy (5); the cure rate is low. In previous years, through considerable investigation (6-8), researchers have been seeking new treatments for cerebral glioma.

At present, numerous anti-tumor drugs have been developed in domestic and foreign fields, but the majority of drugs are expensive and have untoward effects. Drug resistance is also a problem; therefore, the clinical application of these drugs is restricted (9-11). In previous years, numerous new drugs for the treatment of glioma have been developed. Carmustine, as a cell-cycle phase nonspecific alkylating antineoplastic agent commonly used in the treatment of brain glioma (12), inhibits DNA synthesis and RNA production by alkylating DNA and RNA, as well as blocking the activity of DNA polymerases. It has the most notable effect on cell cycle transition between the G1 phase and S phase, blocks $\mathrm{S}$ phase progression and even has an impact on cells at the G0 phase. However, long-term use of carmustine may lead to delayed myelosuppression. In the present study, carmustine was used as a positive control. New drug treatments with high efficiency, low toxicity and low price have become the focus of research in recent years. Tumstatin, which is used in the present study, is a novel tumor angiostatin from active fragments of the angiogenesis inhibition region in the thrombospondin-1 protein and angiostatin linked via a lysine. It consists of 24 amino acids, with a molecular weight of 2,707 kDa. It was developed and synthesized by GL Biochem Ltd. (Shanghai, China). The present study focuses on researching a novel tumstatin that affects C6 glioma cells, and investigating the mechanism of its inhibition effect on glioma by detection of apoptosis and mitochondrial membrane potential changes in glioma cells (13). The present study aims to provide a theoretical basis for additional research on the novel tumstatin treatment of gliomas.

\section{Materials and methods}

Cells. The C6 brain glioma cell line was purchased from the Shanghai Institute of Cellular Biology of Chinese Academy 
of Sciences (Shanghai, China). Cells were maintained in Dulbecco's modified Eagle's medium (Nanjing KeyGen Biotech Co., Ltd., Nanjing, China) with $10 \%$ fetal calf serum (Tianjin Haoyang Biological Manufacture Co., Ltd., Tianjin, China) at $37^{\circ} \mathrm{C}$ in an incubator with $5 \% \mathrm{CO}_{2}$.

Reagents. The mitochondrial membrane potential assay kit with JC-1 (catalog no. C2006), and the cell cycle and apoptosis detection kit (catalog no. C1052) were purchased from Beyotime Institute of Biotechnology (Haimen, China). Ethidium bromide (catalog no. E8751), dimethyl sulfoxide (DMSO) and MTT were purchased from Sigma-Aldrich (EMD Millipore, Billerica, MA, USA). Acridine orange (catalog no. 1AB10220) was purchased from Ding Guo Changsheng Biotechnology Co., Ltd. (Beijing, China). The novel tumstatin was designed by Laboratory of Chemistry and Molecular Biology Institute of Frontier Medical Sciences, Jilin University (Changchun, China) and synthesized by GL Biochem Ltd. (Shanghai, China), with a purity of 98\%. Carmustine (catalog no. 1407011) was purchased from Jinyao Pharmaceutical Co., Ltd. (Tianjin, China; serial number).

Main instruments. The Nikon ECLIPSE 80i fluorescence microscope (Nikon Corporation, Tokyo, Japan), a $\mathrm{CO}_{2}$ incubator (model, NCO-15AC; Sanyo Manufacturing Co., Osaka, Japan), the AN YANG super clean bench (model: BSC-BOO II B2; Anyang Technology Development Co., Ltd., Suzhou, China), a flow cytometer (BD Biosciences, Franklin Lakes, CA, USA) and a microplate reader (model: 550; Bio-Rad Laboratories, Inc., Hercules, CA, USA) were all used in the present study.

Cellular viability by MTT. At the logarithmic growth phase, C6 brain glioma cells were digested with trypsin (Ameresco, Inc., Framingham, MA, USA), cells were counted, and $100 \mu \mathrm{l}$ of cell suspension was added to each well of a 96-well plate at $37^{\circ} \mathrm{C}$ in a $5 \% \mathrm{CO}_{2}$ atmosphere and incubated for $4 \mathrm{~h}$. When cells attached, plates were randomly divided for the Mock group, carmustine group and novel tumstatin of different concentrations $(1,000,1,500$ and $2,000 \mu \mathrm{g} / \mathrm{ml})$, with a total treatment volume of $20 \mu \mathrm{l} /$ well in 96-well plate. The Mock group was treated with culture medium at an equal volume, and each group had 8 wells. At $37^{\circ} \mathrm{C}$ and in a $5 \% \mathrm{CO}_{2}$ atmosphere for 24, 48 and $72 \mathrm{~h}$, each well was incubated for $4 \mathrm{~h}$ with MTT $(20 \mu 1)$. The reaction was then terminated with DMSO $(150 \mu \mathrm{l} /$ well), and cells were shocked for $10 \mathrm{~min}$ on the plate oscillator. An enzyme immunoassay instrument detected the absorbance, and absorption wavelength was set at $490 \mathrm{~nm}$.

Acridine orangelethidium bromide (AO/EB) double staining to detect cells apoptosis. C6 brain glioma cells in the logarithmic growth phase were digested with $0.25 \%$ trypsin. The cell suspension was adjusted to $3 \times 10^{5}$ cells $/ \mathrm{ml}$ and seeded onto 6-well plates at $37^{\circ} \mathrm{C}$ in a $5 \% \mathrm{CO}_{2}$ atmosphere for $4 \mathrm{~h}$. This was then randomly divided for the Mock group, the carmustine group and novel tumstatin of different concentrations $(1,000$, 1,500 and $2,000 \mu \mathrm{g} / \mathrm{ml}$ ), and 2 wells were allocated to each group (50 $\mu \mathrm{l} /$ well in a total volume of $2 \mathrm{ml} /$ well in 6 -well plate). Coverslips were removed, covered with cells and then placed on a slide. This was followed by the dropwise addition of $5 \mu \mathrm{l}$ of $\mathrm{AO} / \mathrm{EB}$ dye to the coverslips. Slides were observed immediately by fluorescence microscopy, and images were captured (x20). The number of apoptotic cells per field was counted, and the apoptosis rate was calculated (\% apoptotic cells $=$ number of apoptotic cells/total number of cells x100\%).

Detection of mitochondrial membrane potential (JC-1). C6 brain glioma cells in the logarithmic growth phase were digested with $0.25 \%$ trypsin and inoculated in 6-well plates with $3.0 \times 10^{5}$ cells $/ \mathrm{ml}$, at $37^{\circ} \mathrm{C}$ in a $5 \% \mathrm{CO}_{2}$ atmosphere for $4 \mathrm{~h}$. This was randomly divided for the Mock group, the carmustine group and novel tumstatin of different concentrations $(1,000,1,500$ and $2,000 \mu \mathrm{g} / \mathrm{ml})$, and two wells were allocated to each group $(50 \mu \mathrm{l} /$ well with $2 \mathrm{ml})$. Carbonyl cyanide m-chlorophenylhydrazone (CCCP; according to the ratio of $1: 1,000)$ was added to the culture medium of each cell as a positive control group. In the carmustine group and novel tumstatin of different concentrations, $0.5 \mathrm{ml} \mathrm{JC}-1$ staining liquid (Beyotime Institute of Biotechnology, Haimen, China) was added to each well. Following incubation for $20 \mathrm{~min}$ at $37^{\circ} \mathrm{C}$, the supernatant was discarded, and cells were rinsed twice with JC-1 (1X) buffer in an ice bath, and $1 \mathrm{ml}$ of culture medium was added to each well. This was observed under the fluorescence microscope, at the excitation wavelength of $490 \mathrm{~nm}$ and emission wavelength of $530 \mathrm{~nm}$, and images were captured (x20).

Cell cycle detection by flow cytometry. Subsequent to treatment (method 2), cells were collected with cold PBS, percussed into a single cell, centrifuged, washed twice with PBS and resuspended with $500 \mu \mathrm{l}$ PBS. The following components were then added: $1 \mathrm{mg} / \mathrm{ml}$ propidium iodide (PI); $10 \mathrm{mg} / \mathrm{ml} \mathrm{RNase} \mathrm{A;}$ and $0.01 \%$ Triton-X100, protected from light for $30 \mathrm{~min}$ at $37^{\circ} \mathrm{C}$. The cell cycle was detected by flow cytometry, and the percentage of each cell cycle accounted for the results.

Analysis of apoptosis by Annexin V-fluorescein isothiocyanate (FITC)/PI. Following treatment (method 2), cells were collected with cold PBS, resuspended with $195 \mu \mathrm{l}$ Annexin V-FITC and incubated for 10 min away from light. PI $(10 \mu \mathrm{l})$ was then added, and cells were mixed gently in an ice bath (protected from light) and detected by flow cytometry. The results were expressed as apoptosis rate.

Statistical analysis. Statistical analysis was performed by SPSS 13 statistical software (SPSS, Inc., Chicago, IL, USA). The data were expressed as the mean \pm standard deviation. Statistical significance was compared between the treatment and the control groups by one-way analysis of variance. $\mathrm{P}<0.05$ was considered to indicate a statistically significant difference.

\section{Results}

Cellular viability by MTT. The results demonstrated the effect of different dose models of tumstatin on C6 glioma cells. At $24 \mathrm{~h}$, cells were spindle-shaped, which was observed in each experimental group under a fluorescence microscope, and no significant difference was observed between each group $(\mathrm{P}>0.05)$. At $48 \mathrm{~h}$, novel tumstatin significantly inhibited $\mathrm{C} 6$ glioma cell growth $(\mathrm{P}<0.05)$, whereas growth of the Mock 
Table I. Effect of novel tumstatin on the activity of C6 cells.

\begin{tabular}{lccc}
\hline & \multicolumn{3}{c}{ OD value } \\
\cline { 2 - 4 } Group & $24 \mathrm{~h}$ & $48 \mathrm{~h}$ & $72 \mathrm{~h}$ \\
\hline Mock group & $0.201 \pm 0.034$ & $0.247 \pm 0.037$ & $0.250 \pm 0.043$ \\
Carmustine group $(100 \mu \mathrm{g} / \mathrm{ml})$ & $0.194 \pm 0.030$ & $0.193 \pm 0.034^{\mathrm{a}}$ & $0.221 \pm 0.039$ \\
Novel tumstatin group $(1,000 \mu \mathrm{g} / \mathrm{ml})$ & $0.201 \pm 0.025$ & $0.231 \pm 0.063$ & $0.218 \pm 0.032$ \\
Novel tumstatin group $(1,500 \mu \mathrm{g} / \mathrm{ml})$ & $0.199 \pm 0.037$ & $0.194 \pm 0.036^{\mathrm{a}}$ & $0.212 \pm 0.025$ \\
Novel tumstatin group $(2,000 \mu \mathrm{g} / \mathrm{ml})$ & $0.200 \pm 0.028$ & $0.183 \pm 0.035^{\mathrm{a}, \mathrm{b}}$ & $0.215 \pm 0.023$ \\
\hline
\end{tabular}

Data are expressed as the mean \pm standard deviation; $\mathrm{n}=40$; ${ }^{\mathrm{a}} \mathrm{P}<0.05$ compared with the Mock group and the novel tumstatin group; ${ }^{\mathrm{b}} \mathrm{P}>0.05$ compared with the carmustine group. OD, optical density.

group markedly increased. Significant differences were visible in the novel tumstatin $(2,000 \mu \mathrm{g} / \mathrm{ml})$ group compared with the Mock group and novel tumstatin $(1,000 \mu \mathrm{g} / \mathrm{ml} ; \mathrm{P}<0.05)$. No significant difference was observed in the novel tumstatin $(2,000 \mu \mathrm{g} / \mathrm{ml})$ group compared with the carmustine group ( $P>0.05)$. At $72 \mathrm{~h}$, each experimental group showed accelerated and spiral cell growth. Among these groups, cells in the carmustine group and the novel tumstatin group grew more slowly compared with the Mock group. At $72 \mathrm{~h}$, the novel tumstatin group had no inhibitory effects on C6 cell growth (Table I and Fig. 1).

AO/EB double staining immunofluorescence and morphological observation of cell apoptosis. C6 glioma cells were treated with novel tumstatin for $48 \mathrm{~h}$, and using $\mathrm{AO} / \mathrm{EB}$ staining, apoptosis was observed under a fluorescence microscope. The results showed a large number of cells in the Mock group were stained green, and the cells were spindle-shaped with a whole nucleus and clear demarcation. With the increase in drug concentration, the number of normal cells was gradually reduced, while the number of apoptotic cells, which emitted red fluorescence in the cytoplasm and nucleus, increased. Significant differences were visible in the novel tumstatin $(2,000 \mu \mathrm{g} / \mathrm{ml})$ group compared with the Mock group and novel tumstatin $(1,000 \mu \mathrm{g} / \mathrm{ml} ; \mathrm{P}<0.05)$. No significant difference was observed in the novel tumstatin $(2,000 \mu \mathrm{g} / \mathrm{ml})$ group compared with the carmustine group ( $\mathrm{P}>0.05$; Table II and Fig. $2 \mathrm{~A})$.

Effects of the novel tumstatin on C6 brain glioma cell mitochondrial membrane potential. Under the fluorescence microscope, in the CCCP positive control group, mitochondrial membrane potential of C6 glioma cells was lost completely following treatment with novel tumstatin $(10 \mu \mathrm{m})$ for $20 \mathrm{~min}$, and JC-1 staining showed green fluorescence. In the Mock group, the majority of cells were stained red, and cells had slender protuberance. Following treatment with the novel tumstatin $(2,000 \mu \mathrm{g} / \mathrm{ml})$ group on C6 glioma cells for $48 \mathrm{~h}$, the majority of cells showed green fluorescence, and no cell had protrusions or appeared rounded, suggesting that cells were apoptotic; red fluorescent cells were spindle-shaped. However, the protuberance was short compared with the normal control group, the novel tumstatin $(1,000 \mu \mathrm{g} / \mathrm{ml})$ group and the novel tumstatin $(1,500 \mu \mathrm{g} / \mathrm{ml})$ group. Significant differences were

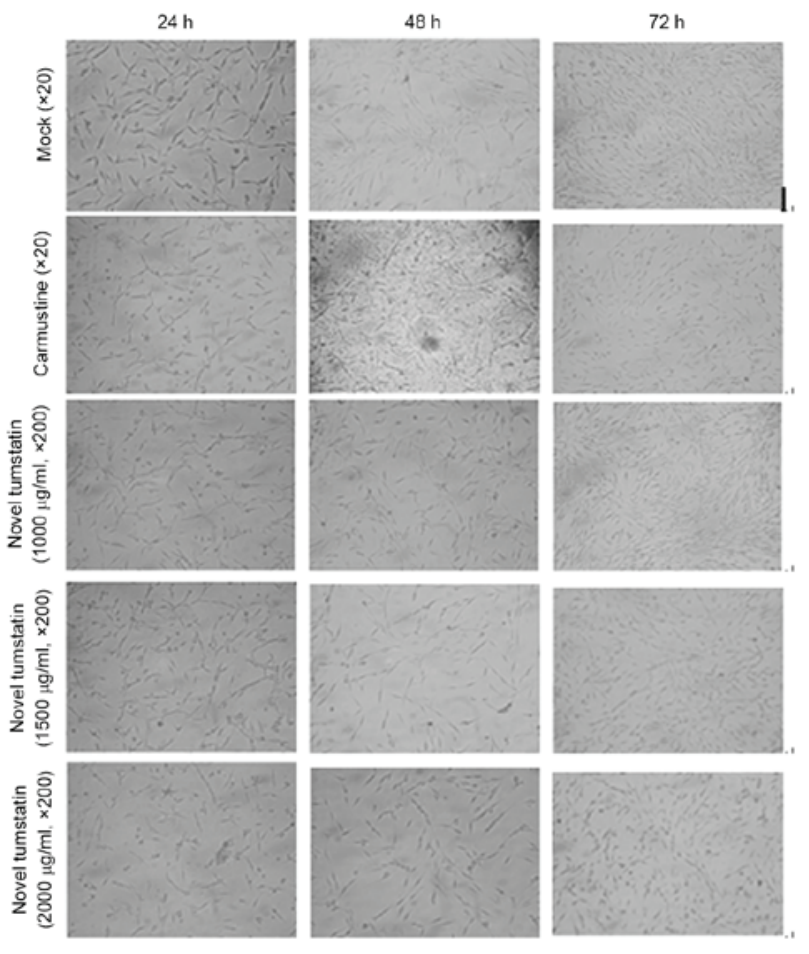

Figure 1. Inhibitory effects of different doses $(0,1,000,1,500$ and $2,000 \mu \mathrm{g} / \mathrm{ml})$ of novel tumstatin on C6 glioma cells at 24, 48 and $72 \mathrm{~h}$. The effects of novel tumstatin were determined by the MTT assay.

visible in the novel tumstatin $(2,000 \mu \mathrm{g} / \mathrm{ml})$ group compared with the Mock group and the novel tumstatin $(1,000 \mu \mathrm{g} / \mathrm{ml})$ group $(\mathrm{P}<0.05)$. No significant difference was observed in the novel tumstatin $(2,000 \mu \mathrm{g} / \mathrm{ml})$ group compared with the carmustine group ( $\mathrm{P}>0.05$; Table II and Fig. 2B).

Effects of the novel tumstatin on brain glioma cell cycle and apoptosis. The present study showed that at $48 \mathrm{~h}$, novel tumstatin altered the cell cycle. In the novel tumstatin $(2,000 \mu \mathrm{g} / \mathrm{ml})$ group, the G0/G1 phase rate increased significantly, while the number of cells in the $\mathrm{S}$ phase decreased significantly $(\mathrm{P}<0.05)$. Significant differences were visible in the novel tumstatin $(2,000 \mu \mathrm{g} / \mathrm{ml})$ group compared with the Mock group and the novel tumstatin $(1,000 \mu \mathrm{g} / \mathrm{ml})$ group $(\mathrm{P}<0.05)$. No significant difference was observed in the novel 
Table II. Apoptotic effect of novel tumstatin on C6 glioma cells after $48 \mathrm{~h}$.

$48 \mathrm{~h}$

Group

Mitochondrial membrane potential

AO/ED double staining

CCCP positive control group

Mock group

$74.80 \pm 17.52$

$20.00 \pm 6.20$

$10.00 \pm 2.00$

Carmustine group $(100 \mu \mathrm{g} / \mathrm{ml})$

$39.85 \pm 4.38^{\mathrm{a}}$

$44.20 \pm 11.43^{\mathrm{a}}$

Novel tumstatin group $(1,000 \mu \mathrm{g} / \mathrm{ml})$

$18.60 \pm 5.02$

$18.40 \pm 4.92$

Novel tumstatin group $(1,500 \mu \mathrm{g} / \mathrm{ml})$

$29.80 \pm 3.42$

$35.80 \pm 8.28^{\mathrm{a}}$

Novel tumstatin group $(2,000 \mu \mathrm{g} / \mathrm{ml})$

$40.20 \pm 6.83^{\mathrm{a}, \mathrm{b}}$

$43.80 \pm 5.01^{\mathrm{a}, \mathrm{b}}$

Data are expressed as the mean \pm standard deviation; $\mathrm{n}=30$; ${ }^{\mathrm{a}} \mathrm{P}<0.05$ compared with the Mock group and the novel tumstatin group; ${ }^{\mathrm{b}} \mathrm{P}>0.05$ compared with the carmustine group. CCCP, carbonyl cyanide m-chlorophenylhydrazone; AO/ED, acridine orange/ethidium bromide.

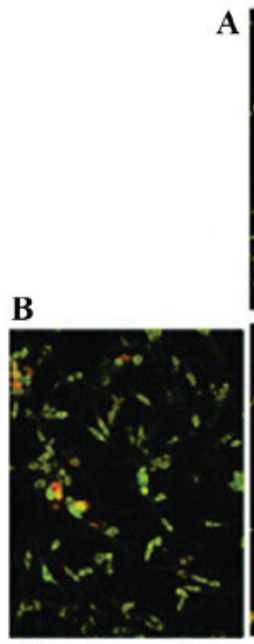

Negative control $(\times 20)$
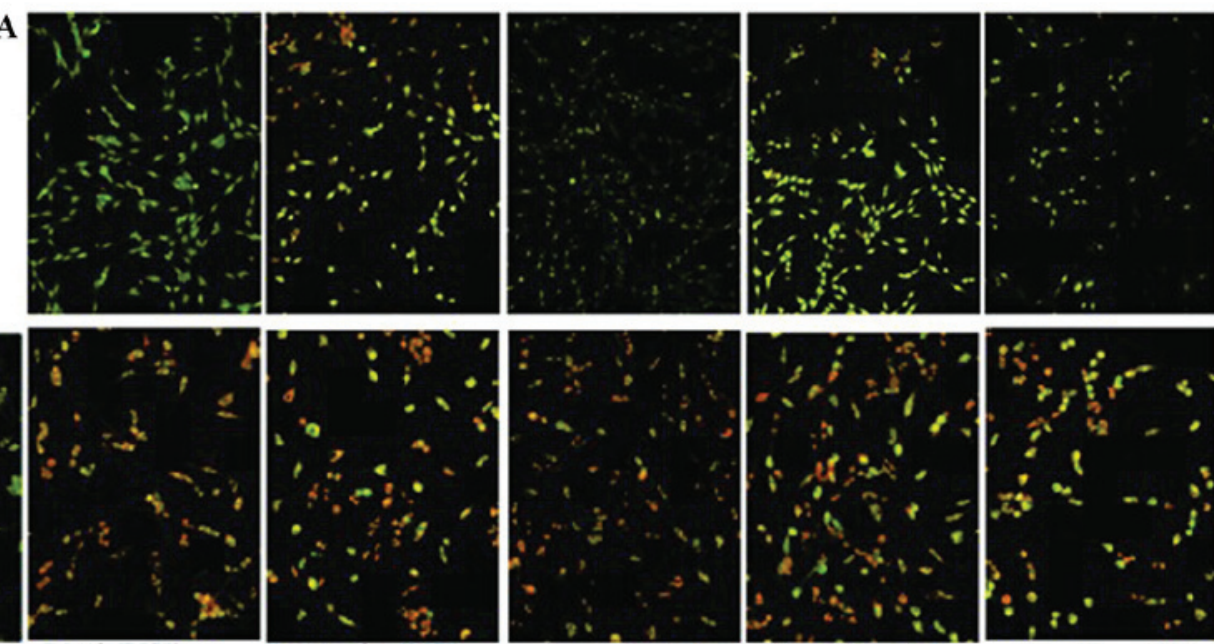

Mock $(\times 20)$

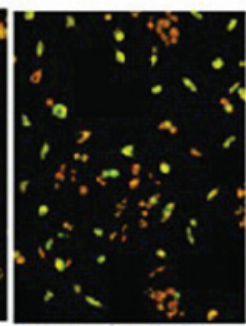

Carmustine

$(\times 20)$

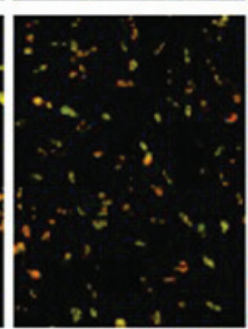

Novel tumstatin $(1000 \mu \mathrm{g} / \mathrm{ml}, \times 20)$

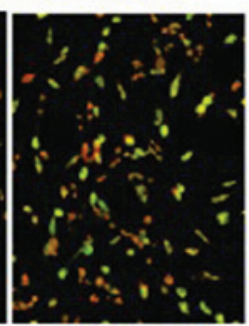

Novel tumstatin $(1500 \mu \mathrm{g} / \mathrm{ml}, \times 20)$

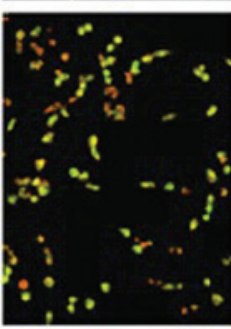

Novel tumstatin $(2000 \mu \mathrm{g} / \mathrm{ml}, \times 20)$

Figure 2. Apoptotic effects of novel tumstatin on the C6 cells after 48 h. (A) C6 glioma cells were treated by novel tumstatin for 48 h, using acridine orange/ethidium bromide staining for observation of cell apoptosis. (B) Mitochondrial membrane potential assay determined the apoptotic effect.

tumstatin $(2,000 \mu \mathrm{g} / \mathrm{ml})$ group compared with the carmustine group (Table III and Fig. 3). Results showed that the novel tumstatin $(2,000 \mu \mathrm{g} / \mathrm{ml})$ group evidently promoted apoptosis of C6 glioma cells.

\section{Discussion}

In previous years, the incidence rate of malignant tumors has been gradually rising. In brain tumors, the incidence of malignant gliomas is the most evident (12), which accounts for $\sim 35-60 \%$ of intracranial tumors (14). The pathogenesis of the disease remains unclear, and there has been no major breakthrough in treatment of the disease. At present, surgery combined with chemotherapy and radiotherapy reduces the recurrence and metastasis of tumors; however, the cure rate is low and there has been no treatment breakthrough. It is the focus of clinical research on effective glioma treatment.

According to studies in the literature, numerous antitumor drugs have been investigated, but the majority of the drugs are expensive and have adverse reactions. There are also problems of drug resistance; therefore, the clinical application of these drugs is restricted (9-11). Therefore, current studies are focused on searching for efficiency, low toxicity, efficacy and stability of antitumor drugs, and an ideal peptide drug will possess these advantages precisely. In the present study, the effects of tumstatin were observed on neurogliocytoma through an in vitro experiment using C6 glioma cells.

The development of tumors is a complex process and is associated with cell apoptosis. The imbalance between cell proliferation and apoptosis was associated with tumorigenesis and development. Therefore, inhibition of tumor cell proliferation and inducing the apoptosis of tumor cells have become important methods for the treatment of cancer (15-18). The present study used the MTT method and light microscopy to assess the inhibition of proliferation and induction of apoptosis. The results revealed that novel tumstatin has an inhibitory effect on the proliferation of C6 glioma cells, and the most notable function appears at $48 \mathrm{~h}$; the novel tumstatin $(2,000 \mu \mathrm{g} / \mathrm{ml})$ group showed significant inhibition of cell proliferation compared with the Mock group and the novel 
Table III. Novel tumstatin impact on the cell cycle and apoptosis of C6 glioma cells.

\begin{tabular}{llccc}
\hline Group & G0/G1-phase & S-phase & G2/M-phase & Apoptosis rate, $\%$ \\
\hline Mock group & $46.41 \pm 8.57$ & $49.67 \pm 9.94$ & $3.92 \pm 4.00$ & $4.88 \pm 0.81$ \\
Carmustine group $(100 \mu \mathrm{g} / \mathrm{ml})$ & $62.68 \pm 2.98$ & $36.23 \pm 3.49$ & $1.08 \pm 0.55$ & $36.78 \pm 8.33$ \\
Novel tumstatin group $(1,000 \mu \mathrm{g} / \mathrm{ml})$ & $52.88 \pm 2.71$ & $44.36 \pm 0.34$ & $2.78 \pm 2.63$ & $10.90 \pm 0.97$ \\
Novel tumstatin group $(1,500 \mu 1 / \mathrm{ml})$ & $58.82 \pm 1.70$ & $40.09 \pm 2.32$ & $1.10 \pm 0.65$ & $30.96 \pm 4.16$ \\
Novel tumstatin group $(2,000 \mu \mathrm{l} / \mathrm{ml})$ & $67.75 \pm 3.27^{\mathrm{a}, \mathrm{b}}$ & $28.88 \pm 2.32^{\mathrm{a}}$ & $2.77 \pm 2.09$ & $45.96 \pm 1.71$ \\
\hline
\end{tabular}

Data are expressed as the mean \pm standard deviation; $\mathrm{n}=15$; ${ }^{\mathrm{a}} \mathrm{P}<0.05$ compared with the Mock group and the novel tumstatin group; ${ }^{\mathrm{b}} \mathrm{P}>0.05$ compared with the carmustine group.
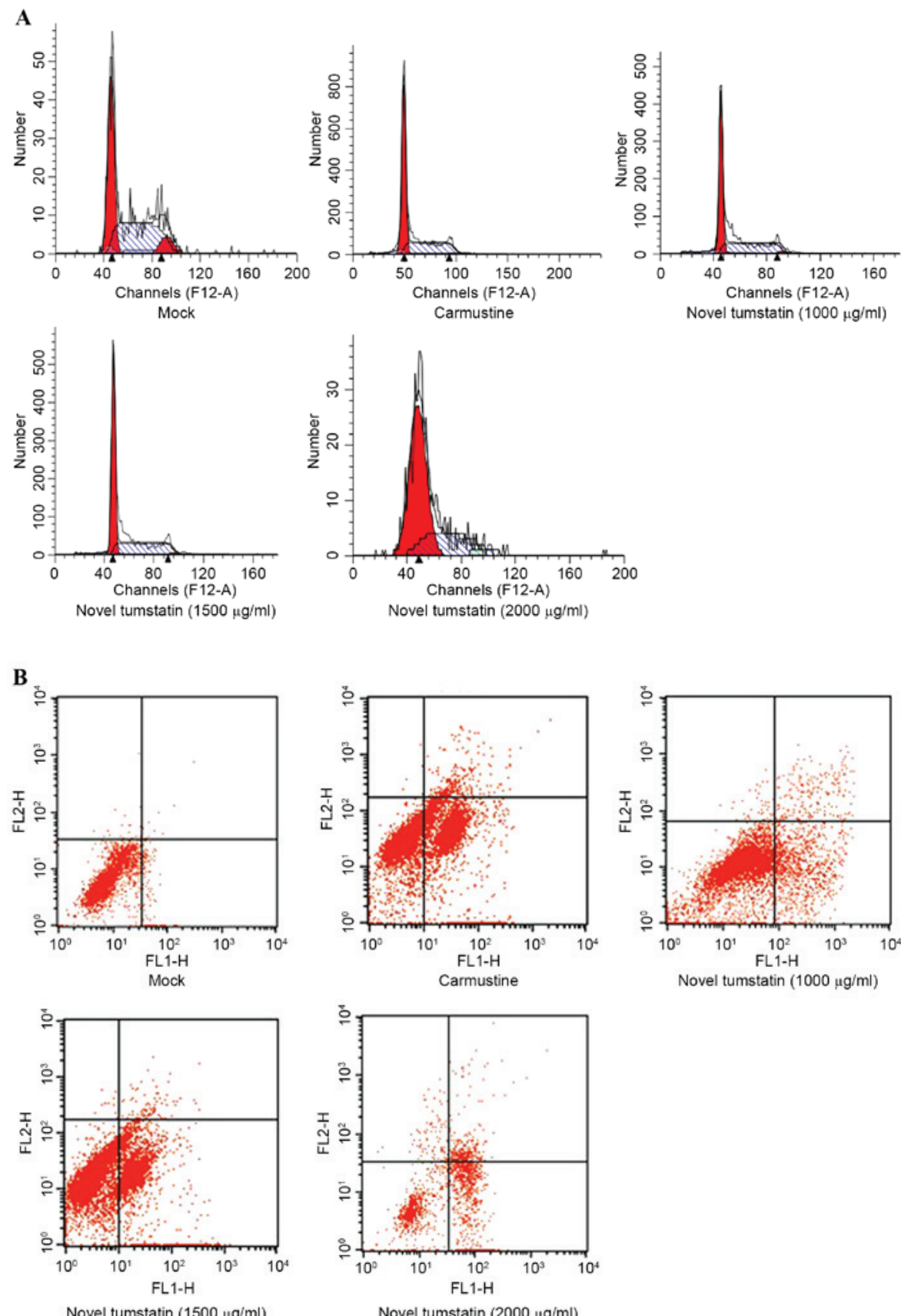

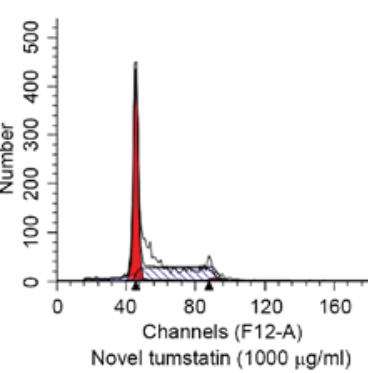

Novel tumstatin $(1000 \mu \mathrm{g} / \mathrm{ml})$
Novel tumstatin $(1500 \mu \mathrm{g} / \mathrm{ml})$

Novel tumstatin $(2000 \mu \mathrm{g} / \mathrm{ml})$

Figure 3. (A) Effects of different doses of novel tumstatin on the cell cycle of C6 glioma cells after $48 \mathrm{~h}$. Cells were treated with different doses $(0,1,000,1,500$ and $2,000 \mu \mathrm{g} / \mathrm{ml}$ ) of novel tumstatin and carmustine for $48 \mathrm{~h}$, then analyzed by flow cytometry. (B) Effects of different doses of novel tumstatin on the cell apoptosis of C6 glioma cells after $48 \mathrm{~h}$. Cells were treated with different doses $(0,1,000,1,500$ and 2,000 $\mu \mathrm{g} / \mathrm{ml})$ of novel tumstatin and carmustine for $48 \mathrm{~h}$, and were then double labeled with Annexin V-fluorescein isothiocyanate/propidium iodide and analyzed by flow cytometry. 
tumstatin $(1,000 \mu \mathrm{g} / \mathrm{ml})$ group $(\mathrm{P}<0.05)$. Under microscopy, the Mock group cells were in good condition, the novel tumstatin $(2,000 \mu \mathrm{g} / \mathrm{ml})$ group had marked effects on inhibition on cell growth, and the number of cells with decreased growth state was low.

Research demonstrates that there are numerous factors inducing cells to be apoptotic; the internal factors are associated with the regulation of certain genes and mitochondrial membrane potential, while the external factors consist of $\gamma$-ray, hypoxia and anti-tumor drugs (19). The level of apoptosis examined by flow cytometry was intuitive and accurate (20-22). In the present study, the apoptosis rate of cells in response to the novel tumstatin was investigated. Tumstatin $(2,000 \mu \mathrm{g} / \mathrm{ml})$ significantly increased the apoptosis rate of C6 glioma cells at $48 \mathrm{~h}$.

The results showed that novel tumstatin and carmustine induce C6 glioma cell apoptosis, thereby increasing the percentage of G0/G1 phase cells; however, no significant difference was observed between the tumstatin $(2,000 \mu \mathrm{g} / \mathrm{ml})$ and carmustine groups $(\mathrm{P}>0.05)$. Following treatment with 2,000 and $1,000 \mu \mathrm{g} / \mathrm{ml}$ tumstatin, a significant difference was observed in the percentage of $\mathrm{G} 0 / \mathrm{G} 1$ phase cells $(\mathrm{P}<0.05)$. Additionally, a more significant decrease was observed in the percentage of S phase cells, DNA synthesis and cell proliferation in the tumstatin $(2,000 \mu \mathrm{g} / \mathrm{ml})$ group compared with the carmustine groups $(\mathrm{P}<0.05)$. Therefore, it was speculated that novel tumstatin arrests the growth of $\mathrm{C} 6$ tumor cells through the G0/G1 phase and induces cell apoptosis, and this effect is time and dose-dependent.

JC-1 is an ideal probe, which is widely used for the detection of mitochondrial membrane potential. When mitochondrial membrane potential is high, JC-1 gathers in the mitochondrial matrix, which forms a polymer with red fluorescence. However, when the mitochondrial membrane potential is low, JC-1 cannot gather in the mitochondrial matrix and becomes a single state, emitting green fluorescence. Detection of the mitochondrial membrane potential by light color may be convenient. The decrease of mitochondrial membrane potential is a hallmark of early apoptotic events $(23,24)$. This research adopts the JC-1 detection model to observe the effect of novel tumstatin on mitochondrial transmembrane potential of $\mathrm{C} 6$ brain glioma cells. The results show that at $48 \mathrm{~h}$, the mitochondrial membrane potential of the novel tumstatin $(2,000 \mu \mathrm{g} / \mathrm{ml})$ group was decreased. Significant differences were visible in the novel tumstatin $(2,000 \mu \mathrm{g} / \mathrm{ml})$ group compared with the Mock group and the novel tumstatin $(1,000 \mu \mathrm{g} / \mathrm{ml} ; \mathrm{P}<0.05)$. No significant difference was observed in the novel tumstatin $(2,000 \mu \mathrm{g} / \mathrm{ml})$ group compared with the carmustine group $(\mathrm{P}>0.05)$. This indicated that novel tumstatin may act directly on the mitochondria of C6 cells, and the mitochondrial membrane permeability increased, causing a decrease in mitochondrial transmembrane potential and thereby inducing cell apoptosis.

$\mathrm{AO} / \mathrm{EB}$ staining was used to detect the apoptosis of C6 cells. The results revealed that novel tumstatin acted on C6 glioma cells after $48 \mathrm{~h}$. A large number of cells were dyed green in the Mock group, and the cells were spindle-shaped with a visible nucleus and clear demarcation. With an increase in drug concentration, the number of normal cells gradually reduced, while the number of apoptotic cells increased, which emitted red fluorescence in the cytoplasm or nucleus. Significant differences in the apoptosis rate were visible in the novel tumstatin $(2,000 \mu \mathrm{g} / \mathrm{ml})$ group compared with the Mock group and the novel tumstatin $(1,000 \mu \mathrm{g} / \mathrm{ml})$ group $(\mathrm{P}<0.05)$. The proportion of apoptotic cells increased gradually with the increase in drug concentration. The results were consistent with the cell cycle and mitochondrial membrane potential. Furthermore, a previous study demonstrated that tumstatin elicits an evident change in the cell cycle by down-regulating cyclinD1 expression (not shown) (25); it causes a significant increase in the number of cells in the G0/G1 phase, but decreases the number of cells in the S phase. Additionally, tumstatin can notably inhibit proliferation, but triggers apoptosis in C6 glioma cells, which is possibly associated with a decline in mitochondrial membrane potential. These results may provide pharmacological evidence for tumstatin as a new anti-tumor drug in the treatment of brain glioma.

In summary, novel tumstatin significantly inhibits the proliferation of C6 glioma cells, inducing cell apoptosis. The possible molecular mechanism of apoptosis is associated with the decrease in mitochondrial membrane potential. On this basis, additional studies will explore the impact of novel tumstatin on the protein expression and cell signal transduction.

\section{References}

1. Auffinger B, Spencer D, Pytel P, Ahmed AU and Lesniak MS: The role of glioma stem cells in chemotherapy resistance and glioblastoma multiforme recurrence. Expert Rev Neurother 15: 741-752, 2015.

2. Sancho-Martinez I and Martin-Villalba A: Tyrosine phosphorylation and CD95: A FAScinating switch. Cell Cycle 8: 838-842, 2009.

3. Eisele G, Roth P, Hasenbach K, Aulwurm S, Wolpert F, Tabatabai G, Wick W and Weller M: APO010, a synthetic hexameric CD95 ligand, induces human glioma cell death in vitro and in vivo. Neuro Oncol 13: 155-164, 2011.

4. Konkankit VV, Kim W, Koya RC, Eskin A, Dam MA, Nelson S, Ribas A, Liau LM and Prins RM: Decitabine immunosensitizes human gliomas to NY-ESO-1 specific T lymphocyte targeting through the Fas/Fas ligand pathway. J Transl Med 9: 192, 2011.

5. Zhao JX, Liu XQ and Dong BJ: Primary study of bevacizumab combined with temozolomide for recurrent glioma. Chin Clin Oncol 39: 920-922, 2011.

6. Do N, Weindl G, Grohmann L, Salwiczek M, Koksch B, Korting $\mathrm{HC}$ and Schäfer-Korting M: Cationic membrane-active peptides-anticancer and antifungal activity as well as penetration into human skin. Exp Dermatol 23: 326-331, 2014.

7. Loud JT, Peters JA, Fraser M and Jenkins J: Applications of advances in molecular biology and genomics to clinical cancer care. Cancer Nurs 25: 110-122, 2002.

8. Hopkins AL and Groom CR: The druggable genome. Nat Rev Drug Discov 1: 727-730, 2002.

9. Okada M, Sato A, Shibuya K, Watanabe E, Seino S, Suzuki S, Seino M, Narita Y, Shibui S, Kayama T and Kitanaka C: JNK contributes to temozolomide resistance of stem-like glioblastoma cells via regulation of MGMT expression. Int J Oncol 44: 591-599, 2014.

10. Sze CI, Su WP, Chiang MF, Lu CY, Chen YA and Chang NS: Assessing current therapeutic approaches to decode potential resistance mechanisms in glioblastomas. Front Oncol 3: 59, 2013.

11. Silber JR, Bobola MS, Blank A and Chamberlain MC: $\mathrm{O}(6)$-methylguanine-DNA methyltransferase in glioma therapy: Promise and problems. Biochim Biophys Acta 1826: 71-82, 2012.

12. Xu JJ, Hong UQ, Zhao W, Hong J, Wen N, Ling QI and Liu XJ: Induction of broccoli polypeptide on apoptosis of C6 glioma cells. Jilin Daxue Xuebao 39: 8-11, 2013.

13. O'Reilly MS, Holmgren L, Shing Y, Chen C, Rosenthal RA, Moses M, Lane WS, Cao Y, Sage EH and Folkman J: Angiostatin: A novel angiogenesis inhibitor that mediates the suppression of metastases by a Lewis lung carcinoma. Cell 79: 315-328, 1994. 
14. Ferguson SD: Malignant gliomas: Diagnosis and treatment. Dis Mon 57: 558-569, 2011.

15. Cobbs CS: Cytomegalovirus and brain tumor: Epidemiology, biology and therapeutic aspects. Curr Opin Oncol 25: 682-688, 2013.

16. Dubrez L, Berthelet J and Glorian V: IAP proteins as targets for drug development in oncology. Onco Targets Ther 9: 1285-1304, 2013.

17. Bartuzi P, Hofker MH and van de Sluis B: Tuning NF- $\kappa B$ activity: A touch of COMMD proteins. Biochim Biophys Acta 1832: 2315-2321, 2013

18. Fang YQ, Q Y, Bai X, Lu XD and Tan Y: Effects of Survivin antisense oligonucleotides on proliferation of hepatic cell line SMMC-7721. Jilin Daxue Xuebao 39: 278-281, 2013.

19. Green DR and Reed JC: Mitochondria and apoptosis. Science 281: 1309-1312, 1998

20. Stuckey DW and Shah K: TRAIL on trial: Preclinical advances in cancer therapy. Trends Mol Med 19: 685-694, 2013.
21. Fink MY and Chipuk JE: Survival of HER2-positive breast cancer cells: Receptor signaling to apoptotic control centers. Genes Cancer 4: 187-195, 2013.

22. Dabbagh A and Rajaei S: The role of anesthetic drugs in liver apoptosis. Hepat Mon 13: e13162, 2013.

23. Adrain $\mathrm{C}$ and Martin SJ: The mitochondrial apoptosome: $\mathrm{A}$ killer unleashed by the cytochrome seas. Trends Biochem Sci 26: 390-397, 2001

24. Vande Velde C, Cizeau J, Dubik D, Alimonti J, Brown T, Israels S, Hakem R and Greenberg AH: BNIP3 and genetic control of necrosis-like cell death through the mitochondrial permeability transition pore. Mol Cell Biol 20: 5454-5468, 2000.

25. Bo Sun, Jiajing Liu, Jiajun Chen, et al: Experiment studies of novel tumstatin on C6 glioma cells in vitro. Chin J Lab Diag 20: 707-709, 2016. 